\title{
DYNAMICS IN PHYSICOCHEMICAL PROPERTIES OF SOILS UNDER OIL PALM PLANTATIONS OF DIFFERENT AGES
}

\author{
Olufemi Osinuga ${ }^{1}$ \\ ${ }^{1}$ Federal University of Agriculture Abeokuta
}

February 15, 2021

\begin{abstract}
Removing forest cover for oil palm plantations has raised questions about climate change problems and debates and their associated impacts. The design of the pruned fronds of the trees does not make them ideal for use as mulch cover on the entire farm, but they are heaped between the plant rows. This research investigated the changes in the physicochemical properties of soils under oil palm plantations of different ages. Soil surface $(0-20 \mathrm{~cm})$ and subsurface $(20-40 \mathrm{~cm})$ samples have been obtained from various ages of oil palm plantations (0-5, 5-10, 10-15 and, 15-20 years). Two distinct samples were taken on the same farm, under alleys and heaped pruned fronds. Soil samples used as a standard (control) were collected from adjacent forest land. Analyses of particle size showed that the soils were sandy loam to sandy clay loam texture soils. Bulk density was low and varied with age and depth. The soils were moderate to slightly acidic $\mathrm{pH}$, relatively low organic carbon, total nitrogen, and available phosphorus contents. Based on the standard ratings, exchangeable bases and cation exchangeable capacity content were also low, while high percent base saturation was observed. Research findings have shown that the soil properties of different ages of oil palm plantations vary and should therefore be handled differently based on of their characteristics. Accumulation of organic residue on the floor of the plantations should be encouraged as this will help to increase organic matter levels.
\end{abstract}

\section{INTRODUCTION}

Oil palm (Elaeis guinensis ) is one of the plantation crops grown in some tropical countries of the world especially Nigeria in addition to cocoa, kola, teak, gmelina, rubber, and cashew as a result of transformations in agriculture. It is cultivated mostly in the southern, eastern, and western parts of the country. Recently, planted areas had increased at a rapid pace, and the increase is significantly evident. Oil palm was adopted and cultivated among the high-value perennial tree crops by individual small-scale growers, private agencies, and government agencies (state and federal). Global oil palm production is approximately 272,055,131 tonnes from 18,917,400 hectares, with Asia (84.1\%) taking the lead, followed by Africa (9\%) (FAO, 2020). It is a major source of oils and fats for human food, livestock feed, and manufacturing of several other domestic products, such as cosmetics, soap, and detergents (Reiger, 2006).

The increase in oil palm demand has resulted in the conversion of natural vegetation into oil palm plantations. The conversion of some rainforests and the use of abandoned logged-off forests into oil palm plantations is expected to have contributed significantly to nutrient losses from both soil and vegetation (Brahene et al., 2016; Rozieta et al., 2016). Deforestation and loss of habitat of critically endangered species (Clay, 2004), a decrease in soil productivity, an increase in soil erosion, and soil biodiversity loss (Comte et al., 2012; Savilaakso et al., 2014), and a substantial increase in greenhouse gas emissions are the detrimental effects of oil palm on the climate (Bates et al., 2008; Hassan et al., 2011). Rising tillage intensity and the conversion of the natural environment to agricultural land have contributed to a decline in soil organic matter levels due to decreased organic carbon inputs and decreased physical conservation of soil organic carbon contents (Chibsa and Ta'a, 2009). 
As a consequence of the combined effects of physical, chemical, and/or biological processes operating at various intensities and on different scales, the classification of soils depends on the degree of spatial heterogeneity (Priyabrata et al., 2008). Research has shown that crop age also leads to soil variability because nutrients are extracted from the soil during harvest for grain, fiber, wood, and crop residues as the crops grow older (Basiron, and Weng, 2004; Aweto and Enaruvbe, 2010). If replenishment with inorganic and/or organic fertilizers is insufficient, nutrient removal can result in a decrease in soil fertility (Okon et al., 2017). There seems to be little or no knowledge as touching the impact of oil palm plantations of different ages on soil physico-chemical properties in the research region to date on various studies on oil palm plantations in Nigeria. Therefore, it is of great importance to assess the quality of soil nutrients in existing oil palm plantations of various maturity ages and to analyze the variability (differences) in the soil properties of these oil palm plantations.

\section{MATERIALS AND METHODS}

Oil palm plantations owned by the Federal University of Agriculture, Abeokuta (FUNAAB), were selected with a reference (control) soil adjacent to the plantations. FUNAAB is located next to Ogun-Oshun River Basin Development Authority (OORBDA), along Alabata road, Abeokuta-Ibadan expressway. It lies in a humid tropical lowland zone with two separate seasons (wet and dry). The wet season runs between March and October, and the dry season runs between November and February. The annual rainfall is between $1000-1500 \mathrm{~mm}$, the annual temperature is between $26-32^{\circ} \mathrm{C}$, and the relative humidity varies between $70-$ $88 \%$. The University superimposes the Basement Complex's pre-Cambrian metamorphic rocks with bed-rock consisting mainly of granitic gneisses, horn-blended gneisses, bounded biotite, quartzite, and quartz schists.

The oil palm plantations ranged from young ones aged around five years to farms as old as twenty years at various maturity ages. Marking an area of $30 \mathrm{~m}$ by $30 \mathrm{~m}$ was followed by sampling. The sampling of farms commenced by establishing four age-based clusters of oil palm plantations into which numerous farms were clustered. A total of twelve parcels, with three parcels for each age group, were chosen as replicates for sampling. Soil samples were obtained at depths of $0-20 \mathrm{~cm}$ and $20-40 \mathrm{~cm}$. There were $0-5,5-10,10-$ 15, and 15-20 years for the different plantation age groups considered. The sampled plots comprised both alleys within the palm rows and pruned and heaped palm fronds. Undisturbed soil samples were collected within the alleys and under heaped trees for bulk density analysis using core samplers. Under the prunings, especially under old heaps, sampling was conducted with care because the top layer had to be separated from the decomposed material sitting just above it. Soils from the sampled spots of various depths from each plantation were put together to obtain a composite sample. A sub-sample was taken, air dried, crushed, and sieved through a $2 \mathrm{~mm}$ sieve for routine laboratory testing, and processed.

Using the hydrometer method (Gee and Or, 2002), particle size composition was performed, bulk density was determined using the core sample method. The $\mathrm{pH}$ was calculated electrometrically using the glass electrode $\mathrm{pH}$ meter in soil-water suspension, soil organic carbon was measured using the digestion method of wet oxidation (Walkley and Black, 1934) and total nitrogen by the digestion method of macro-Kjeldahl (Bremmer and Mulvaney, 1982). The Bray-1 extractant was used to extract available phosphorus (Bray and Kurtz, 1945), while the $\mathrm{P}$ in the extract was determined by the vanado-molybdate blue method (Murphy and Riley, 1962). With $1.0 \mathrm{M} \mathrm{KCl}$ and titrated with $\mathrm{NaOH}$, exchangeable acidity $\left(\mathrm{H}^{+}\right.$and $\left.\mathrm{AI}^{3+}\right)$ was extracted, and with $1.0 \mathrm{M} \mathrm{NH}_{4} \mathrm{OAC}$ at $\mathrm{pH} 7$, exchangeable bases were extracted. The atomic absorption spectrophotometer was used to determine $\mathrm{Ca}^{2+}$ and $\mathrm{Mg}^{2+}$, while the flame photometer read $\mathrm{K}^{+}$and $\mathrm{Na}^{+}$. Cation Exchangeable Capability (CEC) was gotten by the summation of exchangeable bases and total acidity (Chapman, 1965). The base saturation was gotten as the ratio of exchangeable bases to CEC.

Data were analyzed using descriptive statistics to show the relationship between the variables in the plantations. The mean was used to derive the average distribution of the variables, the standard deviation shows how the variables deviate from the mean.

\section{RESULTS}

The physical and chemical properties of the soils were depicted in Tables 1 and 2. The particle size fractions 
varied significantly $(\mathrm{p}<0.05)$ with the age of plantations, and also varied with depths. The sand fractions which ranged between $698-778 \mathrm{~g} / \mathrm{kg}$ were higher in the oil palm plantations, while silt $(50-80 \mathrm{~g} / \mathrm{kg})$ and clay $(172-232 \mathrm{~g} / \mathrm{kg})$ fractions were higher in the forest (uncultivated) soils. Analyses of the particle size revealed that the soil texture was sandy loam and sandy clay loam. Bulk density (BD) values ranged between 0.93$1.25 \mathrm{~g} / \mathrm{cm}^{3}$ and increase with depth. Under both alleys and heaps, the rise in bulk density with depth was noticed, and this could be due to the increasing clay content with depth. In the 0-20 cm layer, soil bulk density levels are relatively lower than those in the 20-40 $\mathrm{cm}$ layer.

The soil $\mathrm{pH}$ values ranged from moderate to slightly acidic except for the reference soil which was neutral. The $\mathrm{pH}$ was higher in the forest surface layer with a value of 7.13 (Table 1) and lowest at the oil palm alley 15-20 years with a value of 5.74 (Table 2). Between the 0-20 and 20-40 cm layers, the results varied significantly. Inside the oil palm alleys, the $\mathrm{pH}$ of the soil appears to be lower than that under heaped fronds and fluctuates as the years of planting increase. Generally, available P did show a significant difference across all the oil palm plantations and soil depths at $\mathrm{p}<0.05$. The average available $\mathrm{P}$ in the topsoil was higher than in the subsoil. The highest value of the uncultivated topsoil was $6.21 \mathrm{mg} / \mathrm{kg}$, followed by $6.10 \mathrm{mg} / \mathrm{kg}$ for the oil palm heaps 15-20 years (Table 1), with the lowest values being $4.43 \mathrm{mg} / \mathrm{kg}$ in the oil palm alley 5-10 years (Table 2).

The soil organic carbon (OC) content was moderate, ranging from $12.4 \mathrm{~g} / \mathrm{kg}$ to $21.7 \mathrm{~g} / \mathrm{kg}$ for $0-20 \mathrm{~cm}$ depth (Table 1) while at $20-40 \mathrm{~cm}$ depth, it ranged from $11.6 \mathrm{~g} / \mathrm{kg}$ to $20.4 \mathrm{~g} / \mathrm{kg}$ (Table 2). The OC content of the reference (uncultivated) site was significantly $(\mathrm{p}<0.05)$ higher than the cultivated sites. Among the oil palm plantations, the 15-20 years old under heaps has the highest OC content $(17.8 \mathrm{~g} / \mathrm{kg})$, while the 1-5 years have the lowest OC content $(11.6 \mathrm{~g} / \mathrm{kg})$. The reference (uncultivated) site's OC content was significantly $(\mathrm{p}<$ 0.05) higher than the sites under cultivation. The OC remained constant for some years after the removal of the current oil palm forest vegetation cover, but after 10 years it was observed that OC accumulation occurred in both alleys and under heaped fronds, especially at a depth of 0-20 cm, aside from that the values observed under heaped fronds were slightly higher. The soil's total nitrogen (TN) was moderate and ranged from $1.18-2.03 \mathrm{~g} / \mathrm{kg}$. The oil palm plantation of 0-5 years and 5-10 years under alley has the same value of $1.18 \mathrm{~g} / \mathrm{kg}$ at the subsoil. The overall distribution of nitrogen content followed a similar trend to the OC distribution and differed significantly with the age of the plantation.

Exchangeable acidity (EA) was low and fluctuated with the years of oil palm cultivation. No substantial variation was found between the overall $\mathrm{EA}$ and the age of the plantations and the depth of the soil at $\mathrm{p}>0.05$. In the uncultivated soil at both depths, the exchangeable bases were higher than in the different age groups of the oil palm soils, both in the alleys and under the palm fronds (Tables 1 and 2). According to the Federal Fertilizer Department's ranking (2012), exchangeable K is low to moderate in both reference soils and oil palm soils. With respect to the soil depth, the mean average $\mathrm{K}$ also showed no noticeable difference but declined with the depth of the soil. The soil's exchangeable $\mathrm{Na}$ is low and the amount seems too small to raise some concerns about any potential physical effect of the soil. Compared to the remaining bases, exchangeable $\mathrm{Ca}$ values were greater, followed by exchangeable $\mathrm{Mg}$. In general, exchangeable $\mathrm{Mg}$ values initially appeared to increase with time in both alleys and under heaped fronds, but declined gradually with further planting age, while the other bases $(\mathrm{Ca}, \mathrm{Na}$ and $\mathrm{K}$ ) fluctuated with the age of the plantations.

Cation Exchange Capacity (CEC) did show significant variation across the plantations at $\mathrm{p}>0.05$, it also significant between the depths (Table 1 and 2). However, at depth of 0-20 cm, the reference soils had the highest CEC value of $6.15 \mathrm{cmol} / \mathrm{kg}$ followed by the $0-5$ years plantation the under alleys with $5.50 \mathrm{cmol} / \mathrm{kg}$ while the 5-10 years plantation under heaps had the lowest value of $5.01 \mathrm{cmol} / \mathrm{kg}$. The soil CEC was low $(<16 \mathrm{cmol} / \mathrm{kg})$ and decreased with depth. There was a general increase in the CEC in both layers after 10-15 years of the alleys and heaped palm fronds to the soil. The percent base saturation (BS \%) of the soils was greater than $50 \%$, and the trend is somewhat inconsistent with the plantation age. The values ranged between $85.3 \%$ and $93.2 \%$ (Tables 1 and 2).

\section{DISCUSSION}


The physical and chemical properties of the soil in different land use may be attributed to differences in the study area's management practices. Soil texture is an inherent property; spatial variations between soils with less variation associated with cultivation could be due to the textural differences found (Brahene et al., 2016). In the 0-20 cm layer, soil bulk density values were comparatively lower when compared to those of 20-40 cm layer where the content of organic matter was very low. This suggests that OM has contributed significantly in enhancing the soil's physical properties, thereby contributing to the soil's structural stability (Germer and Sauerborn, 2008). The BD values obtained cannot hinder root development and penetration.

The low $\mathrm{pH}$ of the soils can be attributed to the nature of the parent materials and the high precipitation that causes the basic cations in the soil to leach intensively (Tweneboah, 2000; Owusu-Bennoah et al., 2000, Oyegoke et al., 2017). Low pH values connote the presence of a positively charged colloidal surface capable of attracting negatively charged ions. The values for oil palm production, however, were acceptable because they were below 7.5 and did not favor oil palm production above that value (Okon et al., 2017). Available soil phosphorus level was low, as the values were between 3-7 mg/kg (Federal Fertilizer Department, 2012). This means that the amount of phosphorous is according to the $\mathrm{pH}$ status of the oil palm plantations. In this land-use system, the higher available $\mathrm{P}$ content within the forest may be correlated with an increase in microbial activity.

The high OC content of soils under heaped fronds is related to the quantity, position, consistency, and temperature and humidity actions on the pruned fronds compared to those under alleys (Kirschbaum, 2000; Comte et al., 2012). As a result of the rapid decomposition of palm fronds, there could be a rise in OC and soil nutrients in planting for less than 10 years, but as the planting age moved to 25 years, the decomposition rate slowed down with decomposed material being covered by overlying palm fronds (Okon et al., 2017). Thus, with the age of the plantation, it is possible to find heaps of different heights (Brahene et al., 2016). Total nitrogen $(\mathrm{TN})$ varies with the quantity of organic matter present in soils, so it has risen without exception, along with improvements in the related status of organic matter. Relatively, TN amount is also determined by organic carbon, which in turn results from plant and root biomass, as well as residues returned to the soil system. The key cause of $\mathrm{N}$ deficiency in tropical soils is extreme leaching and erosion due to high tropical precipitation (Aweto and Enaruvbe, 2010; Osinuga and Oyegoke, 2019).

The low level of basic cations in the plantations results from the effect over time of the continuous uptake of nutrients by the plants. The result shows that the intensity of weathering, cultivation, and use of inorganic acid-forming fertilizers affects the distribution of the cations in the soil system and improves their depletion (Owusu-Bennoah et al., 2000). The low values observed for these basic cations may also be due to the low content of organic matter and the presence of low activity clays of the area (Oyegoke, 2011). Subsequently, the obtained CEC is a function of the $\mathrm{pH}$ and SOM in the soil and, with the age of the oil palms, the value remained reasonably constant in the soil. This is an indication that the soils remain low in CEC at their natural $\mathrm{pH}$ levels, demonstrating the soils' low nutrient retention ability.

\section{CONCLUSIONS}

The study concludes that the distribution of particle size of the soils studied did not vary significantly because they were formed from the same parent material (basement complex rocks). Nutrient mining in plantations is possible as continuous cultivation has been observed to minimize major and minor plant nutrients. Heaping palm fronds were found to yield some advantages over time in terms of carbon content, but could not provide enough nutrients to substitute what the crop used. The rate of decomposition of organic materials increased with high temperatures, and the release of nutrients was faster than plants could quickly absorb and use, and was often subject to losses associated with erosive precipitation. As pruned fronds and cut plants continue to boost the structure of the soils to a point that soil bulk density values are relatively low, the impact of organic matter addition to soils was seen to be beneficial. The study recommends that the accumulation of organic residue on the floor of plantations should be championed as it will help sustain increasing levels of organic matter. It is important to promote more research on how to efficiently use pruned fronds for compost to be spread around the oil palm trees. 


\section{ACKNOWLEDGEMENTS}

The author wishes to appreciate the Directorate of University Farms, Federal University of Agriculture Abeokuta who allowed me to make use of their farms and necessary support rendered in the course of the field work.

\section{CONFLICTS OF INTERESTS}

There are no conflicts to declare.

\section{REFERENCES}

Aweto, A. O., \& Enaruvbe, G. O. (2010). Catenary variation of soil properties under oil palm plantation in South Western Nigeria.Ethiopian Journal of Environmental Studies and Management, 3(1), 1-10. doi.10.4314/ejesm.v3i1.54389

Basiron, Y., \& Weng, C. K. (2004). The oil palm and its sustainability. Journal of Oil Palm Research, 16(1), $1-10$.

Bates, B. C., \& Kundzewicz, Z. W., Wu, S., \& Palutikof, J. P. (2008).Climate change and water . Technical paper of the Intergovernmental panel on climate change, IPCC Secretariat, Geneva, 210pp.

Brahene, S. B., Owusu-Bennoah, E., \& Abekoe, M. K. (2016). Physico-chemical properties of soils under oil palm plantations of different ages. Nature and Faune, 30(1), 54-58.

Bray, R. H., \& Kurtz, L. T. (1945). Determination of total organic and available forms of phosphorus in soils. Soil Science, 59, 222-229.

Bremmer, J. M., \& Mulvaney, C. S. (1982). Total Nitrogen. In: A. L. Page, R. H. Miller, and D. R. Keeney (Eds.), Methods of Soil Analysis. Madison, W.I. American Society of Agronomy, 2, 49-158.

Chapman, H. D. (1965). Cation exchange capacity. In: Black, C. A. (Ed.). Methods of soil analysis. American Society of Agronomy, Madison, pp. 891- 901.

Chibsa, T., Ta'a, A. (2009). Assessment of soil organic matter under four in Bale Highland, Southeast Ethiopia. Soil organic matter in four land use systems: forestland, grassland, fallow land and cultivated land. World Applied Sciences Journal, 6(9), 1231-1246.

Clay, J. (2004). Palm oil . In "World Agricultural and the Environment: A Commodity by Commodity Guide to Impacts and Practices" (Jason Clay, Ed.), Island Press, Wahsington, DC, USA. Pp. 203-235.

Comte, I., Colin, F., Whalen, J. K., Grünberger, O., Caliman, J. P., Gru, O. (2012). Agricultural practices in oil palm plantations and their impact on hydrological changes, nutrient fluxes and water quality in Indonesia: A review. Advances in Agronomy, 116, 71-122. doi:10.1016/B978-0-12-394277-7.00003-8

Federal Fertilizer Department (FFD). (2012). Fertilizer use and management practices for crop production in Nigeria . 4th Edition.; eds V. O. Chude; S. O. Olayiwola; A. O. Osho and C. K. Daudu, Federal Ministry of Agriculture and Rural Development, Abuja, Nigeria. ISSN 115-554X.

FAO. (2020). Food and agricultural data of the world. Production quantities of the oil palm fruit. http://www.fao.org > faostat. Accessed 13/10/2020.

Gee, G. W., Or, D. (2002). Particle size distribution. In: Dane, J.H., Topp, G.C. (Eds) Methods of soil analysis, part 4, physical methods. Soil Science Society of American Book Series No 5, ASA and SSSA, Madison, W.I. 255-293.

Germer, J., \& Sauerborn, J. (2008). Estimation of the impact of oil palm plantation establishment on greenhouse gas balance.Environmental Development and Sustainability, 10(6), 697-716. doi.org/10.1007/s10668006-9080-1 
Hassan, M. N. A., Jaramillo, P. \& Griffin, W. M. (2011). Life cycle GHG emissions from Malaysian oil palm bioenergy development: the impact on transportation sector's energy security. Energy Policy, 39, 2615-2625. doi.org/10.1016/j.enpol.2011.02.030

Kirschbaum, M. U. F. (2000). Will changes in soil organic carbon act as a positive or negative feedback on global warming? Biogeochemistry, 48, 21-51. doi.org/10.1023/A:1006238902976

Okon, M. A., Nwachukwu, M. N. \& Osujieke, D. N. (2017). Differences in physicochemical properties of soils under oil palm plantations of different ages in Ohaji/Egbema, Imo State. (2017). International Journal of Research in Agriculture and Forestry, 4(1), 1-5. doi.org/10.22259/ ijraf.0401001

Osinuga, O. A., \& Oyegoke, C. O. (2019). Degradation assessment of wetlands under different uses: implications on soil quality and productivity. African Journal of Agricultural Research , 17(1), 10-17. doi.10.5897/AJAR2018.12981

Owusu-Bennoah, E., T. W. Awadzi, E. Boateng, L. Krog, H. Breuning-Madsen and O. K. Borggaard. 2000. Soil properties of a toposequence in the moist semi deciduous forest zone of Ghana. West African Journal of Applied Ecology , 1, 1-10. doi.10.4314/wajae.v1i1.40565

Oyegoke, C. O. 2011. Clay Mineralogy of major Soils in Geological Transition Zone; Isolu-Opeji, Ogun State, Nigeria. Unpublished PhD. Thesis University of Agriculture, Abeokuta, Nigeria.

Oyegoke, C.O., Osinuga, O. A., Senjobi, B. A.,Martins, O. (2017). Effects of chemical fertilizers and herbicides on accumulation of some heavy metals in wetlands under different land use types in Odeda, Southwest Nigeria. Moor Journal of Agricultural Research, 18, 1-12.

Priyabrata, S., Chroppa, U. K., \& Debashis, C. (2008). Spatial variability of soil properties and its application in predicting surface map of hydraulic parameters in an agricultural farm. In: Current Science, 95 (7), Sp 1.

Reiger, M. 2006. Introduction to fruit crops . 6th Edition. Harworth Press Inc., New York. Pp26-30.

Rozieta, R., Sahibin, A., Wan Mohd, R. I. (2016). Soil carbon sequestration in different ages of oil palm plantations.American-Eurasian Journal of Agriculture and Environmental Science, 16 (5), 1004-1007. doi.10.5829/idosi.aejaes.2016.16.5.103134

Savilaakso, S., Garcia, C., Garcia-Ulloa, J., Ghazoul, J., Groom, M., Guariguata, M. R., Laumonier, Y., Nasi, R., Petrokofsky, G., Snaddon, J., Zrust, M. (2014). Systematic review of effects on biodiversity from oil palm production. Environmental Evidence , 3, 4. doi:10.1186/2047-2382-3-4

Tweneboah C. K. (2000). Modern Agriculture in the Tropics, with Special Reference to West Africa Cash Crops . Co-Wood Publishers, pp 121-147.

Walkley, A., \& Black, I. A. (1934). Determination of organic matter in soil. Soil Science, 37, 549-556. doi.10.1097/00010694-193401000-00003

Table 1: Physical and Chemical Properties of Soils under Oil Palm Alley and Heaps (0-20 cm)

\begin{tabular}{|c|c|c|c|}
\hline Plantation & Sand & Silt & Clay \\
\hline Age (Years) & $\ldots \ldots \ldots$. g/kg......... & $\ldots \ldots \ldots g / k g$. & $\ldots \mathrm{g} / \mathrm{kg}$. \\
\hline Alley and Reference Soil & Alley and Reference Soil & Alley and Reference Soil & Alley and Reference Soi \\
\hline $0-5$ & 758 & 60 & 182 \\
\hline $5-10$ & 778 & 50 & 172 \\
\hline $10-15$ & 748 & 70 & 182 \\
\hline $15-20$ & 728 & 70 & 202 \\
\hline Uncultivated & 698 & 80 & 222 \\
\hline Heaps and Reference Soil & Heaps and Reference Soil & Heaps and Reference Soil & Heaps and Reference Sc \\
\hline $0-5$ & 748 & 70 & 182 \\
\hline
\end{tabular}




\begin{tabular}{llll}
\hline Plantation & Sand & Silt & Clay \\
\hline $5-10$ & 758 & 60 & 182 \\
$10-15$ & 748 & 70 & 182 \\
$15-20$ & 718 & 70 & 212 \\
Uncultivated & 698 & 80 & 222 \\
\hline
\end{tabular}

Table 2: Physical and Chemical Properties of Soils under Oil Palm Alley and Heaps (20-40 cm)

\begin{tabular}{llc}
\hline Plantation & Sand & Silt \\
\hline Age (Years) & $\ldots \ldots \ldots$ g/kg.............. & $\ldots$ \\
Alley and Reference (Uncultivated Forest) Soil & Alley and Reference (Uncultivated Forest) Soil & Alley a \\
$0-5$ & 748 & 60 \\
$5-10$ & 768 & 80 \\
$10-15$ & 728 & 70 \\
$15-20$ & 718 & 80 \\
Uncultivated & 688 & 70 \\
Heaps and Reference (Uncultivated Forest) Soil & Heaps and Reference (Uncultivated Forest) Soil & Heaps \\
$0-5$ & 748 & 60 \\
$5-10$ & 758 & 70 \\
$10-15$ & 728 & 70 \\
$15-20$ & 718 & 80 \\
Uncultivated & 688 & \\
\hline
\end{tabular}

